Published in: Bart van Klink and Ubaldus de Vries (eds.), Academic Learning in Law. Theoretical Positions, Teaching Experiments and Learning Activities, Edward Elgar: Cheltenham 2016, p. 15-34.

Bart van Klink

\title{
Learning and Aphasia: What Is the Use of Skeptical Legal Education? [final draft]
}

\section{Summary}

Law teachers at the university want students to develop a critical attitude. But what exactly does it mean to be critical and why is it important to be critical? How can a critical attitude be promoted? In this chapter, I intend to elucidate the role that critical thinking may play in legal education. To begin with, I will present the notion of skeptical legal education, which is inspired by Michael Oakeshott's idea of liberal learning but which relativizes its insistence on the non-instrumentality of learning and reinforces its critical potential. Subsequently, I will address some critical questions that may be raised against this notion: Can everything be questioned? Should everything be questioned? And why need law students to be encouraged to be critical? Finally, I will show what the relevance may be of the suspension of judgment that skeptical legal education intends to bring about, both for the practice and the science of law.

\section{$1 \quad$ Critical Thinking}

If one were to ask law teachers at the university what distinguishes academic legal education from professional and vocational training, they probably will refer to the capacity of critical thinking. As academics, we are not satisfied that students are able to reproduce faithfully what they have learnt but we want them to develop a critical attitude towards the things we have told them and the texts we have given them to read. But what exactly does it mean to be critical and why is it important to be critical? How can a critical attitude be promoted and developed? At the core of our modern self-understanding lies the notion of critique. Kant (2003: 54) defined Enlightenment famously as "man's emergence from his self-incurred immaturity" or, more properly, "speechlessness" (Unmündigkeit). In the Critiques that he developed he sought 
to liberate thinking by means of reason from the idées recues handed down by tradition. In contemporary legal theory, the notion of critical thinking seems to be annexed by the Critical Legal Studies movement (CLS). By wearing the banner of 'critical', 'crits' such as Duncan Kennedy, Allan Hunt and Peter Goodrich, ${ }^{1}$ suggest that they have acquired the monopoly of being critical; other, mainstream liberal or conservative approaches have to be dismissed as hopelessly uncritical. 'Critical' in this understanding is connected to a left-wing political agenda that aims at exposing and subverting existing power structures in society.

However, as I have tried to demonstrate earlier (see Van Klink 2013 and Van Klink \& De Vries 2013), there are other and less politically biased ways in which critical thinking can be understood and promoted in legal education that do more credit to the academic ideal of disseminating and generating knowledge for its own sake. This other sense of being critical I intent to capture in my notion of skeptical legal education (SLE). SLE offers a criticalhermeneutic understanding of legal education. It departs, to begin with, from the Kantian tradition that attempts to strengthen people's autonomy by freeing them from their traditional beliefs and prejudices, ${ }^{2}$ because it holds that there is no escape from tradition, except by taking one's cue from particular traditions. Subsequently, it dismisses the politicized, neo-Marxist notion of critical legal education, as advocated by CLS, since it considers teaching to be something else than a preparation for political activism. Though it deems political reflection in the study of law to be valuable, it does not promote concrete political goals. As Max Weber (1989: 19) puts it: "politics has no place in the lecture-room."

SLE is inspired by Oakeshott's idea of liberal learning. Michael Oakeshott belongs to the tradition of secular humanism that aims at initiating students in a 'great conversation' which shapes them intellectually as well as morally (Kronman 2007: 86-87). In The Voice of Liberal Learning (a collection of essays published in 2001), Oakeshott characterizes learning as a strictly noninstrumental activity. Learning does not follow a pre-established plan and has no final destination. It is an adventure with an uncertain and unpredictable outcome: "This engagement is an adventure in a precise sense. It has no preordained course to follow: with every thought and action a human being lets

\footnotetext{
${ }^{1}$ For an introduction to the 'first wave' of Critical Legal Studies, see Kelman (1987).

2 A Kantian view of autonomy in educational theory is defended, for instance, by Carrington (2004) and Nussbaum (2003), which I will discuss briefly in section 3.
} 
go a mooring and puts out to sea a self-chosen but largely unforeseen course" (Oakeshott 2001: 11).

In this chapter, I want to show how critical thinking is promoted in SLE, how it differs from Kantian and 'critical' approaches to critical thinking, and what scientific and practical purposes it may serve. First, I will describe Oakeshott's view on education, characterized as liberal learning (section 2). Second, I will present the notion of SLE, which builds on the idea of liberal learning but which relativizes its insistence on the non-instrumentality of learning and reinforces its critical potential (section 3 ). ${ }^{3}$ In addition, some skeptical methods and techniques within the study of law will be discussed. Third, I will address three kinds of critical questions that may be raised against it: Can everything be questioned? Should everything be questioned? And why need law students to be encouraged to be critical? (section 4). Finally, I will show what the (individual, scientific and social) relevance may be of the suspension of judgment that skeptical legal education intends to bring about, both for the practice and the science of law (section 5).

\section{$2 \quad$ Liberal Learning}

According to Oakeshott (2001: 10), the human world is essentially a "place of learning." Throughout his whole life man is engaged in learning. Within this education permanente schools and universities occupy a privileged position. Characteristic for these educational organizations is, to begin with, that those involved are recognized and recognize themselves as learners, besides possible other roles they may fulfill in society. Subsequently, learning in educational organizations is focused on the learning of something specific. It does not aim at promoting intellectual development, spiritual growth or the broadening of one's horizon in general, but at acquiring knowledge about a particular subject, within a particular discipline, with the help of the methods and conceptual tools typical for the discipline at hand. Finally, in schools and universities learning is not an instrumental activity, but a goal in itself. Knowledge is acquired not only, or not predominantly, for external purposes. Learning takes place in a separated sphere, far away from our daily cares and concerns. Therefore, Oakeshott (2001: 15) characterizes learning as liberal, not in the political sense but in the existential sense of 'liberated' or 'freed': at least for a

\footnotetext{
${ }^{3}$ Sections 2 and 3 are partly derived from Van Klink (2013) and Van Klink \& De Vries (2013). I have expanded my characterization of SLE and added some concrete examples of skeptical methods and techniques.
} 
couple of years, learners do not have to worry too much about "satisfying contingent wants". What the university offers, is "the gift of an interval" (Oakeshott 2001: 114).

Oakeshott (2001: 69) describes education as a transaction between generations, which aims at introducing newcomers to an "intellectual, imaginative, moral and emotional inheritance". The inheritance is shaped and reshaped in an on-going conversation in which people are engaged in understanding themselves and their world. In order to be able to participate in this conversation, learners have to learn first to speak the language and to recognize the different voices that can be discerned within this language. Every academic discipline constitutes a language of its own, with its own rules, by means of which certain aspects of the world and human existence can be expressed. It is the task of the teacher to teach the students the rules of the language and to show how one can make one's own contribution to the ongoing conversation. Liberal learning is an initiation in this art of conversation.

According to Oakeshott, the 'free' conversation that takes place at universities was threatened by various developments within the British educational system in the $50 \mathrm{~s}$ and $60 \mathrm{~s}$ of the last century and modern society in general. In ordinary life, he argues, mainly one language is spoken - the "language of appetite" (Oakeshott 2001: 33). It is a language full of clichés by means of which superficial impressions and emotions can be expressed in general terms that are recognizable and repeatable for everyone. Its sole purpose is to satisfy immediate needs in the quickest, easiest and cheapest way possible. Increasingly, learning is transformed into some form of applied education. That means that education is used for socializing students and preparing them for certain tasks in society. Instrumental learning replaces liberal learning and, as a consequence, teaching is reduced to the training of a series of technical functions (cf. Oakeshott 2001: 13). Nowadays, education is more and more subjected to the logic of economic reason that requires universities to apply business models, based on output, efficiency and economic utility as benchmarks of quality (see Francot-Timmermans \& De Vries 2010). Due to these developments, schools and universities are no longer free spaces of learning, where learners acquire knowledge mainly for its own sake.

In modern universities there is an increasing tendency to reduce learning to skills training. Oakeshott argues that education never coincides with the training of specific techniques, not even in vocational education. In order to know how to do something, one has to understand first what one is doing. In 
Oakeshott's view, knowledge contains two components: information and judgment. Information consists of both facts (for instance about what statutes are and where they can be found) and rules that prescribe how a specific skill (such as the interpretation of a certain statute) has to be carried out. Judgment is the knowledge that makes it possible to interpret information and to assess its relevance and, moreover, to determine which rule has to be applied in a given case and which actions are required by this rule. Without knowledge of this kind one would not be able to learn a skill: "Before any concrete skill or ability can appear, information must be partnered by 'judgment,' 'knowing how' must be added to the 'knowing what' of information" (Oakeshott 2001: 49). A lawyer, for instance, needs to know more than the content of the legal norms; $\mathrm{s} /$ he also must know when in a given case which norm $\mathrm{s} /$ he has to apply and how that norm has to be interpreted in the case at hand. This kind of knowledge cannot be expressed in rules or, in other words, be translated into information. It gives us guidance in situations where there are no specific rules or methods available or where we do not know which rule or method to apply. Generally speaking, when we learn a language - whether it is English or Spanish or the language of philosophy or the law's language - it does not suffice to learn the rules only. A competent speaker is someone who is able to express himself or herself in a way that is not prescribed explicitly by the rules. Judgment cannot be learned, because it cannot be made an independent object of study. The teacher transmits it implicitly when giving information: "It is implanted unobtrusively in the manner in which information is conveyed, in a tone of voice, in the gesture which accompanies instruction, in aside and oblique utterances, and by example" (Oakeshott 2001: 60). Students develop their judgment by recognizing and appreciating the individual intelligence at work in the way in which the teacher thinks and speaks, in his or her personal style and mode of expression.

In the past, nobody gave lessons in the art of conversation, but it had to be learnt by listening to competent speakers engaged in conversation. There are no shortcuts for learning by way of simple techniques or "easy methods" (Oakeshott 2001: 179). Only by 'submerging' oneself in the practice of scholarship one can become a fully-fledged participant in this practice. 


\section{$3 \quad$ Skeptical Legal Education}

Following Oakeshott, I conceive of education as an initiation in the art of conversation in which scholars of a certain discipline are engaged. This does not imply that students have to be trained to be their master's voice; on the contrary, they have to develop their own voice. For that purpose, it is important to encourage students to reflect critically and to develop their faculty of judgment. What matters is that students learn to make their own assessment of the information that they receive from teachers while reading literature, listening to lectures and engaging in discussions. Students cannot and do not invent the standards of evaluation from nowhere, but they have to build hermeneutically and critically on the values that are already accepted within the community of legal scholars. Whereas Carrington (2004: 149) conceives of "moral and intellectual autonomy" as the ultimate goal of education, I would prefer to speak of the moral and intellectual integrity to use one's 'own' faculty of judgment. The student's autonomy is always related and relative to the intellectual environment in which s/he is raised. So it is a critical attitude that has to be developed starting from an 'uncritical' (or self-evident) background of shared opinions and beliefs. One can never get rid of the background of accepted ideas from which one perceives reality, that is, in terms of Gadamer (2013: 313-315), the pre-judices that make up one's horizon. However, through reflection and discussion one may get a better understanding of this background or horizon and one may put some shared opinions and beliefs into question by confronting them with other accepted ideas and replace them by other ideas that then will pre-structure one's perception of reality.

It is exactly in this hermeneutic sense that SLE intends to contribute to critical thinking: knowledge claims should never be taken for granted, but questioned and discussed from within the context of accepted ideas handed down through particular traditions. Contrary to the Enlightenment project, it does not conceive of education as a liberation from one's pre-judices by the force of reason alone, but as a constant questioning (or 'playing-off') of pre-judices on the basis of other pre-judices in order to preserve the ones that seem to be, for the time being, the best fitting. According to Martha C. Nussbaum (2003: 269), the "examined life" Socrates strived for consists of a life "that accepts no belief as authoritative simply because it has been handed down by tradition or become familiar through habit, a life that questions all beliefs and accepts only those that survive reason's demand for consistency and justification." 4

4 Nussbaum (1997: chapter 1) discusses in depth Socrates' rejection of the authority of tradition and his sole reliance on the authority of reason. Nussbaum (1997: 294) does 
However, as follows from Oakeshott's characterization of liberal learning as an initiation in an on-going scholarly conversation, reason can never stand on its own but has to build on habit, tradition and authority. ${ }^{5}$ Against 'critical' approaches, SLE puts forward that being critical is not the same as understanding society according to some pre-established political scheme. The 'critique' exercised by Duncan Kennedy and others is one way of being critical, because it can make students aware of power structures in law and society at large. Legal education may engage in political analysis; it should, however, refrain from political engagement. Academic education teaches students not to embrace any kind of political ideology (either of a conservative or a progressive strand), but instead to question and debunk it. The general aim of education is to raise intellectual rather than political awareness by feeding epistemological doubt and uncertainty, so that students learn to assess knowledge claims critically. ${ }^{6}$

In order to promote reflection and develop the faculty of judgment within SLE, in particular three conditions have to be met. These conditions which I will discuss below concern (i) the student's activity inside and outside the classroom, (ii) the manner in which the teacher transfers knowledge and (iii) the institutional context of the faculty management respectively. I have derived them partially from Oakeshott's notion of liberal learning as described above, but I have added some points in order to make the learning process more (or more explicitly) critical and challenging.

To begin with, legal education should give more room for student participation in courses. According to Oakeshott, students have to learn the language of a specific discipline, so that one day they are able to generate new utterances in this language. For that purpose it is essential that students participate more actively in class than Oakeshott acknowledges. One may learn a lot from reading texts and listening to competent speakers, but in order to master a language fully, one must be given regularly the opportunity to speak for

acknowledge that "in tradition lies much that has stood the test of time, that should command people's respect." In her view, convention and tradition are "essential food for the mind." However, she warns that food should not be confused with "the strength in the mind that the food is supposed to produce" (ibid.). Ultimately, it is reason, or the "test of argument" (Nussbaum 1997: 18), that decides whether conventional and traditional beliefs and practices should be followed; they have no authority or value in themselves.

${ }^{5}$ For a more detailed analysis of the role of authority and hierarchy in legal education, see Van Klink (2013). In their contribution, Francot \& Corrias (chapter \#), following Arendt, also stress the importance of authority for education.

${ }^{6}$ For a detailed critique on Kennedy's view on critical legal education, see Van Klink (2013). 
oneself. This may be accomplished by means of group discussions, presentations, moot courts and so on, and solely in classes of limited size. ${ }^{7}$ The cases discussed in law courses should give a representative overview of the law as it is understood in legal doctrine and should encourage students to make their own assessment of it (without 'politicizing' the classroom as advocated by Kennedy 1995 and 2004). Furthermore, students should be encouraged to continue their learning process outside the classroom through various kinds of study-related extracurricular activities such as reading groups, online blogs, and student seminars.

What is required, furthermore, is that law teachers convey information from a detached point of view. That is, they should present the law as it is, as much as possible independently from their own ethical and political preferences. ${ }^{8}$ This descriptive, seemingly 'neutral' account of the law does not presuppose that understanding law is in itself a neutral or value-free activity. On the contrary, law teachers are required to present the law as it is and to expose the legal, moral and political values on which the law (and their understanding of it) is based, however without identifying themselves with these values. If they evaluate the current law and give recommendations to amend it, they have to make clear that they are not describing the law as it is at a certain moment in time but are expressing their personal opinion about how the law ought to be in the future. Value judgments are controversial in science, because their validity depends on the acceptance of certain values and ultimately of a worldview (or an ideology in 'critical' terms) whose truth can never be established by scientific means. So when teachers are evaluating the law, they should make clear on the basis of which values they are reasoning, how they understand these values in the given situation, and how their evaluation is connected to their general worldview. As Weber (1989: 25-26) argues, teachers may offer examples of hypothetical reasoning: if one accepts a specific value (for instance, democracy), one has to acknowledge certain rights as well (such as the freedom of speech), without committing themselves (nor the students) to the acceptance of this value. In addition, the pros and cons of the means suggested to reach a certain end can be discussed scientifically (which, in

\footnotetext{
7 So I agree with Nussbaum (2003: 273) that in legal education, classes have to be much smaller.

8 This requires what $\operatorname{Raz}(1979: 158)$ calls "non-committed detached statements": "Since one may know what the law is without knowing if it is justified, there must be a possibility of making legal statements not involving commitment to its justification."
} 
Weber's view, will discourage an uncritical acceptance of certain values ${ }^{9}$ ). Reasoning in such a way gives students the opportunity to arrive at a different assessment, building on different values, on a different understanding of the same values, or on a different worldview. Similarly, law teachers should explain and justify on the basis of what theoretical assumptions and what sources they make factual assertions about the content of the law.

Knowledge is always fallible and disputable, when it comes to both normative and factual statements. In order to give students a feeling for the fragility of knowledge, it is important that teachers, in group discussions with students, take a counter position against the communis opinio in the group at hand, question it and demonstrate its ultimate groundlessness, as in Socratic dialogues. ${ }^{10}$ Inspired by Socrates, ancient Greek skeptics such as Sextus Empiricus developed practices of argumentative inquiry that are meant to expose internal contradictions within a given position. As a result, the dispute remains undecided and one has to suspend one's judgment (epoche). ${ }^{11}$ 'Skepsis' means an inquiry or an examination guided by reason and in search for truth, however in vain perhaps this search may be. In the interim that the university offers interrupts have to be built in that halt temporarily the creation of knowledge. Learning also involves the experience that one does not know or does not know enough. In ancient skepticism, the suspension of judgment served to attain a peaceful state of mind (ataraxia) so that one no longer worries about truth and falsity anymore. Being unable to speak, one enters a tranquil phase of aphasia. In my view, the ultimate goal of the infinite questioning is not tranquility or peace of mind but, on the contrary, an increased awareness that knowledge is always a temporary and fallible construction.

Finally, on the institutional level, the faculty management has to provide for a mixture of teachers with different political, cultural, and religious backgrounds. If they are exposed to a variety of opinions, students will soon discover that truth in science is always a matter of debate. As Oakeshott argues, education is an introduction to a shared heritage. However, the heritage that is handed over from one generation to the other is not a fixed entity, but is changed in

\footnotetext{
9 Weber (1989: 22) puts it as follows: "Anybody who is a reasonable teacher has as his first duty to teach his students to acknowledge 'inconvenient' facts, I mean facts which are inconvenient for their party opinion."

10 For an introduction to the Socratic method in legal education, see Areeda (1996).

${ }^{11}$ Burnyeat (1983) gives an insightful description of the skeptical practice of inquiry.
} 
every transmission. ${ }^{12}$ Every teacher will give his/her own version of the canonical texts, depending on the theoretical perspective and worldview s/he has adopted. Not one dominant voice should be heard, but a plurality of voices. This plurality of voices will inevitably be a limited plurality, because not everyone will be allowed to speak. In the selection of teachers not only academic requirements are applied (teachers have to have the right qualifications), but also standards of civility (teachers have to meet some standard of decency and political correctness). ${ }^{13}$ Kennedy (2004: 15) is undoubtedly right that the mainstream in law schools is quite moderate. Generally speaking, law teachers are conservative in the sense that they want to protect what they deem to be valuable in the law as it is. They tend to resist radical change because they believe - for good reasons ${ }^{14}$ - that a legal system can only function properly if the law is more or less stable and predictable. However, within this mainstream many different (liberal, republican, conservative, communitarian, feminist and other) positions can be discerned and, if one listens carefully, one may even hear some radical and 'critical' tones. In order to set the stage for a (by necessity limited) plurality of voices, the curriculum should not only consist of courses where the 'black letter law' is taught, but also of courses in which the law's efficacy and legitimacy and its historical development can be discussed on a more principled and theoretical level: in particular, legal sociology, legal philosophy, law and politics, law and ethics, and legal history. Although these so-called 'meta-juridical' and historical courses are doomed to remain in the periphery, as Kennedy (2004: 36) notices, they are central for critical reflection on the law as it is and how the law ought to be according to mainstream law teachers who teach 'black letter law'.

In working groups, various techniques and methods can be used in order to encourage the kind of questioning that SLE calls for. I already referred to Socratic dialogues, skeptical argumentation techniques and Weber's idea of hypothetical reasoning. A contemporary practice of questioning is offered by deconstruction which, through close reading, aims at exposing binary oppositions in texts (for instance between man and woman, black and white, nature and culture) and subverting the hierarchical relation between the terms involved. Deconstruction is a never-ending activity, because every reading can

12 This follows from Gadamer's characterization of understanding as application (Gadamer 2013: 36-38 ff.).

13 Universities will not be inclined to give voice to teachers who, for instance, have overtly fascist sympathies or engage in criminal activities.

${ }^{14}$ See next section, point (ii). 
itself be deconstructed, ad infinitum: "The end-point of deconstructive thought, as Derrida insists, is to recognize that there is no end to the interrogative play between text and text. Deconstruction can never have the final word because its insights are inevitably couched in a rhetoric which lies itself open to further deconstructive reading" (Norris 2002: 84). Moreover, Bal Sokhi-Bulley has applied Edward De Bono's thinking hat-method to legal education in the Legal Research workshops that she teaches at Queen's University Belfast. Following this method, students are asked, first, to identify the key issues regarding a particular topic - e.g., the London riots in 2011 - and, subsequently, to write a paper on this topic from a specific perspective, either a legal positivist, or a Critical Race Theory (CRT), or a feminist, or a Foucauldian perspective. By doing so, students experience that the same story can be told in different ways, depending on the perspective one takes, and that "alternative truths" are possible (Sokhi-Bulley 2013: 18). Finally, in the so-called Law \& Lounge experiment carried out by Bald de Vries at Utrecht University College (described in Van Klink \& De Vries 2013: 45-49), the student's activity is maximized and the teacher's involvement is reduced to a minimum. Students are exposed to difficult classical texts in the field of legal philosophy (such as Hobbes' Leviathan and Mill's On Liberty) and they have to read and discuss them in the way they think is appropriate. The teacher is present as an observer and can only be consulted on organizational matters; he abstains from giving the 'right' answer to the questions raised.

\section{$4 \quad$ Questioning the Questioning}

Several kind of questions can be put forward against the practices of questioning that SLE promotes. Firstly, one can ask, from an epistemological point of view, whether it is possible to question everything. How to question current opinions if the ground one stands on is itself unstable and shaky? Secondly, from a moral point of view, the question is whether everything should be questioned. Why should we as teachers give up all the things we believe in so dearly, if only by way of make-believe and for the sake of argument? According to Nussbaum (1999: 742), skeptical detachment is not so much a help but a hindrance to ethical and legal reasoning. Thirdly, practically and politically speaking, what is the point of making law students more critical? One could argue, on the one hand, that law students do not need to be critical because they have to be educated to serve 'the system'. After their graduation, they will probably occupy important positions in society - as law makers, judges, attorneys, legal advisors to the court, the administration or the 
legislature, and so on - and for that purpose they should accept, by and large, the things as they are, including the existing power relations. ${ }^{15}$ On the other hand, it can be maintained that law students are already critical enough, since they are trained to examine cases very carefully in order to find clever arguments to support their position and to refute the opponent's arguments. ${ }^{16}$

\section{(i) Can everything be questioned?}

It is a hermeneutic truism, but therefore not less true, that one can only question some convictions on the basis of other convictions that one does not question - either for argument's sake, as Socrates did, or for real, because one believes in them. If one, for instance, argues that the parliamentary system nowadays fails to represent the voter's interests, one has to presuppose some idea of representation. Ludwig Wittgenstein (1977) also argues that the practice of doubting is only possible in a context where some things are excluded from doubt. In his view, radical skepticism is not possible, because all doubt is embedded in underlying beliefs. As a consequence, not everything can be questioned at the same time. However, building on some accepted ideas, which are part of conventional or traditional knowledge, one may criticize other ideas: if one believes that political representation is a matter of serving the voter's interests, one can criticize the idea that political parties are a valuable intermediary between state and society. As Odo Marquard argues, the skeptic is not someone who knows nothing; he only knows nothing for sure. ${ }^{17}$ He may accept certain beliefs, not because he is certain about them, but out of habit or for the sake of convenience. ${ }^{18}$

So what SLE offers, by acknowledging the inevitability of pre-judices in understanding, is not radical epistemological skepticism but a modest and mild variety of skepticism that rejects any claim to absolute truth or ultimate foundations. It values questions over answers and doubt over certainty. SLE does not aim at questioning everything simultaneously, but only those ideas that seem to have a weak position in the existing network of ideas (according to

\footnotetext{
15 According to Kennedy (2004), legal education in the US is aimed at "the reproduction of hierarchy."

16 These two, seemingly contradictory questions were raised to me by two students at the symposium on Ancient Skepticism, organized by the Faculty association of Utrecht Philosophy Students (FUF), on 31 October 2013 in Utrecht, The Netherlands.

17 Marquard (2007: 77): "[D]er pyrrhonische Skeptiker weiss also beilebe nicht nichts, er weiss nur nichts Absolutes. Der Skeptiker zersetzt nicht, er mässigt."

18 Marquard (2007: 78): "Skepsis is Usualismus.".
} 
the criterion of coherence) or do not seem to fit our perception of reality (following the criterion of correspondence). The teacher may, for educational purposes, question some mainstream beliefs, not so much to refute them because that would only mean a transfer of certainty from one belief to another -, but to heighten the burden of proof on those who hold these beliefs to be self-evident. Thus, the suspension of judgment that SLE intends to bring about, is never complete but partial and temporary, and the questioning takes place from within a context in which some beliefs are not questioned (for the time being).

\section{(ii) Should everything be questioned?}

In her critique of Ancient skepticism (Sextus Empiricus) and postmodern skepticism (Derrida and Fish), Nussbaum (1999: 742) argues that skeptical detachment is detrimental to ethical and legal reasoning: "by depriving us of commitments to the importance of things outside ourselves, skepticism has even deprived us of the information we need to make sense of social ills and to respond to them in a humanly appropriate way." However, skepticism does not equal nihilism or radical value relativism, because both the denial and the equalization of values presuppose a certainty of belief that skepticism abstains from. What skepticism intends to bring about is a suspension of judgment, so that we no longer worry about the truth or falsity of our opinions. It does not necessarily deprive us of our commitments, as long as we do not conceive of our opinions as absolute, invariable and eternal truths.

SLE does not require that teachers give up their ethical convictions and emotional responses entirely. They are solely asked to present their value judgments for what they are: fallible opinions which are debatable and have to be debated within the community of both teachers and learners. By presenting their opinions with some distance and stressing their provisional character, they leave room for other opinions. This does not mean that 'anything goes'. To begin with, teachers are allowed to favor one position over another as long as they do not rule out the possibility of other positions and discuss them in a fair

and balanced way. Subsequently, they cannot be required to pay the same amount of respect to every kind of opinion: opinions that are commonly perceived as inappropriate or indecent can be dismissed. The playfield of scholarly conversation is determined by the range of acceptable and accepted values within a certain academic community, that is, by current standards of 
civility. ${ }^{19}$ Finally, for didactic reasons, teachers may choose not to take sides within a discussion or to take a counter-position against the mainstream in order to make students think for themselves. So skeptical detachment serves an educational and ethical purpose: by confusing or even 'paralyzing'20 reason, opinions are questioned that are too easily taken for granted.

\section{(iii) Why need law students to be critical?}

It may be argued that law students do not have to be encouraged to think critically, either because they are expected to serve 'the system', or because they are already critical enough, clever as they are in discovering arguments in difficult cases. In its academic ambition, the study of law is no vocational training, although most of the law students will afterwards occupy jobs in legal and political practice. It is aimed at understanding the existing law in a given field and in a particular time and place (e.g., contemporary environmental law in the member states of the European Union), evaluating the law as it is and making suggestions for how it ought to be. For these purposes, it is necessary that students are trained to reflect critically on how things are arranged legally because, on a factual level, current descriptions of the law may not be adequate and, on a normative level, the law may be in need of improvement. Innovative analysis and assessment can only be carried out if one looks with some distance at the legal system at hand and one does not identify oneself fully with the present arrangements. From a political perspective, it can be objected that, by describing a certain collection of norms as law and thereby, in Kelsenian terms, accepting the basic norm of a given legal order, one endorses and supports the existing political system. That is no doubt true. If you want to make a revolution, the law is usually not your friend. The law only allows for small and incremental change, although these changes can be in the long run quite substantial. According to Bruno Latour, slowness is a fundamental quality of the law. Unlike science, law aims at stabilizing its system of rules: "A

19 These standards should not be taken too strictly, in order to prevent what Kronman (2007: 90) calls a "culture of political correctness" which, in his view, has dominated the humanities since the 1960s and has undermined his ideal of secular humanism. I do believe, however, that some notion of civility is needed, since one cannot expect scholars to take seriously opinions that are generally considered to be morally inacceptable or wrong.

20 This expression is used in Burnyeat (1983: 133). 
premium is put on legal stability but there is no such thing as scientific stability." ${ }^{21}$ Therefore, law resists radical change:

Although one might speak admiringly of 'revolutionary science', 'revolutionary laws' have always been as terrifying as courts with emergency powers. All those aspects of law that common sense finds so irritating - its tardiness, its taste for tradition, its occasionally reactionary attitudes - are essential to law's functioning. ${ }^{22}$

You may regret that (as the 'crits' do) or you may welcome that (as I do). However, these political and pre-scientific preferences do not affect the academic ambition of law as a scientific discipline. As generally in science, the point is not merely to change the world, but first and foremost to understand it. So, given its focus on knowledge dissemination and creation, legal education does not aim at producing servile civil servants, but at providing an inspiring intellectual environment for critical minds to flourish.

Whether law students are already critical enough, can be questioned. In mainstream law courses, students do learn to analyze cases and to construe arguments supporting their own position and undermining their opponent's position. However, critical thinking is more than an exercise in skillful legal reasoning. According to Nussbaum (2003: 272), "legal education all too often blurs the distinction between sophistry and philosophy, clever argument and argument that tracks the truth." In order to promote critical thinking, it is important, as I already argued (see section 3), that the curriculum - next to courses where the 'black letter law' is taught - also provides for courses in which the law's efficacy and legitimacy and its historical development are discussed on a more fundamental level. In courses such as legal sociology, legal philosophy, law and politics, law and ethics, and legal history, students learn that the law can be approached from many different perspectives and cannot be reduced to a mere "set of technical maneuvers," as Nussbaum (2003: 271) puts it. In Nussbaum's view, legal education serves an ethical mission: law schools have to prepare students for global citizenship by cultivating their humanity. ${ }^{23}$ Whatever one may think of this ambitious ideal, and its desirability and attainability, it cannot determine the scientific virtue of education. I prefer to conceive of legal education's end primarily in scientific terms as a matter of moral and intellectual integrity, that is, the ability to assess knowledge claims critically drawing from the reservoir of accepted ideas. Exposed to different perspectives and approaches, law students will acquire a

\footnotetext{
${ }^{21}$ Latour (2013: 242).

22 Latour (2013: 242-243).

${ }^{23}$ See, more extensively, Nussbaum (1997: chapter 2).
} 
feeling for the fragility of knowledge, its uncertainty and open-endedness. Moreover, they will experience that scientific knowledge is a matter of permanent debate and does not generate ready-made answers or quick solutions.

\section{The Metaphysics of Questioning}

SLE is an attempt to enhance critical thinking in legal education. In this sense, it is indebted to what may be called the modern metaphysics of questioning. Like Kantian and 'critical' approaches to education, it beliefs that reflection, discussion and criticism will move mankind forward in its search for perfection. However, in contrast to the Enlightenment project, it does not assume that this questioning starts from nowhere and is carried out by an 'empty' mind, deprived of traditional and conventional knowledge. It also departs from the "ethics of supersession" that, according to Kronman (2007: 118), characterizes the contemporary ideal of scholarly research, inspired by the ideal of Bildung, which requires scholars to be 'original' and to break with their predecessors. ${ }^{24}$ Instead, SLE accepts the hermeneutic presupposition that some ideas can only be questioned when other ideas are taken for granted ideas that belong to the intellectual inheritance that is hand down through education. There is no escape from tradition, except by exploring and exploiting the critical resources available in the various scientific traditions developed within different academic disciplines. As Oakeshott (2001: 69) indicates, education is a transaction between generations, which aims at introducing newcomers to an "intellectual, imaginative, moral and emotional inheritance." Each discipline constitutes a language of its own by which certain aspects of our existence are revealed. Students have to learn the language first, before they are able to make new utterances that are not prescribed explicitly by the rules. Against CLS, SLE does not conceive of education as an activist enterprise. A skeptical attitude entails that knowledge claims and value judgments are questioned from a detached point of view rather than from a particular political ideology. If one wants to engage oneself politically, there is a world outside the academia.

${ }^{24}$ Kronman (2007: 118) puts it like this: "A scholar does not aim to stand where his ancestors did. He seeks originality, but accepts the transience of his own original achievements." On the ideal of Bildung, see also the contribution of Francot-Timmermans \& Corrias to this edited volume. 
In three ways SLE intends to promote critical thinking. Firstly, it stresses that learning not only consist of a passive reception of texts and lectures, as Oakeshott assumes, but also requires an active involvement of students. By means of group discussions, presentations, moot courts and extracurricular activities such as reading groups, students can develop their own voice in the on-going conversation. In terms of examination, papers and open questions are much better suited for promoting reflection and critical thinking than multiplechoice questions, which teachers often resort to nowadays for convenience's sake. ${ }^{25}$ Secondly, teachers have to adopt in their mode of teaching a detached point of view. This means that they are asked to present their knowledge claims and value judgments as fallible opinions which are to be discussed within the community of both teachers and students. Moreover, teachers have to incorporate interrupts in the learning process by using skeptical methods and techniques that hamper the process of knowledge acquisition temporarily. Confronted with alternative truths (as in the thinking hat-method), inconvenient truths (through hypothetical reasoning in Weber's proposal) or incompatible truths (as in deconstructive reading practices), students are compelled to suspend their judgment. A transient phase of aphasia is crucial to the creation of knowledge: it give students the opportunity to reflect and to discover new insights and expressions in order to find a way out of the aporia they are stuck in. Speechlessness, from which the Enlightenment sought to save us, thus appears to be a condition for speech. Finally, the faculty management has to take care that in the curriculum a plurality of voices can be heard by selecting teachers from different social and intellectual backgrounds. Moreover, next to the regular law courses, philosophical, empirical and historical courses have to be provided that promote reflection on the foundation and the functioning of law, now and in the past.

A last question that is perhaps still not answered satisfactorily: what is the use of skeptical legal education? All this questioning, where is good for? I want to answer this question on three levels: an individual, scientific and social level. On an individual level, questioning can make people very insecure. In the face of truth, one cannot but fail. Every knowledge claim or value judgment may be criticized from some perspective or other. At the same time, it can be a liberating experience to discover that there is not one truth or dominant perspective that one is forced to accept. According to Marquard (2007: 18), skepsis is not the "cultivation of helplessness" (Pflege der Ratlosigkeit) but the "sense for the division of powers" (Sinn für Gewaltenteilung). That means that,

25 Nussbaum (2003: 273) also stresses the importance of paper-writing in basic courses. 
in the collision of different opinions, the subject can free him/herself - not from opinion itself - but from the oppressive force of one particular (scientific, political, social, moral, religious or other) opinion. On a scientific level, questions are more important than answers. As Gadamer argues, scientific inquiry always starts with a question. ${ }^{26}$ Every answer is provisional and gives rise to new questions, and so the endless search for truth continues. Progress in science is achieved, not by abandoning everything that was accepted before, but by critically building on the ideas of earlier generations of scholars. In contrast, Weber (1989: 12) states that "[e]very scientific 'fulfilment' means new 'questions'; it asks to be 'surpassed' and made obsolete." In his view, the hope of being superseded is what drives every scholar: "To be overtaken in science is (...) not only the fate of every one of us, but our common goal. We cannot work without hoping that others will get further than we do" (ibid.). However, old and already accepted scientific ideas will continue to influence and inspire new ideas, which are never created ex nihilo. In that sense, SLE departs from the modern Weberian ethics of supersession and replaces it with a hermeneutic ethics of "effective history." 27 On a social level, finally, SLE provides law students with a critical and detached perspective on law and society in general. Equipped with a healthy dose of skepticism, they won't take everything for granted in the present legal and political order (nor will they reject everything out of hand), but raise critical and uneasy questions in order to improve it, starting from the values that this order intends to serve. Since they are well aware of the fallibility and fragility of knowledge, they won't be inclined to embrace any political ideology or to follow political leaders uncritically. Skepticism does not necessarily make life easier, but it at least makes it easier to endure.

26 Gadamer (2013: 370 ff.) calls this the hermeneutic "priority of the question" (Vorrang der Frage). On the relation between question and answer, see also Waldenfels (1994: 125-133).

${ }^{27}$ See Gadamer (2013: 312 ff; in German: Wirkungsgeschichte). 


\section{Literature}

\section{Areeda 1996}

Phillip E. Areeda, 'The Socratic Method', Harvard Law Review 1996, p. 911922.

\section{Burnyeat 1983}

M.F. Burnyeat, 'Can the Skeptic Live His Skepticism?', in: Myles Burnyeat (ed.), The Skeptical Tradition, Berkeley: University of California Press 1983, p. 117148.

\section{Carrington 2004}

Paul Carrington, 'Reproducing the Right Sort of Hierarchy', in: Duncan Kennedy, Legal Education and the Reproduction of Hierarchy. A Polemic against the System, New York: New York University Press 2004, p. 145-153.

\section{Francot \& De Vries 2010}

Lyana Francot \& Bald de Vries, "Adieu Von Humboldt? Over Domme Organisaties en Slimme mensen (Adieu Von Humboldt? About Ignorant Organizations and Smart People)", in: Het Universitaire Bedrijf. Over Professionalisering van Onderzoek, Bestuur en Beheer (The University Enterprise. About Professionalization of Research, Governance and Management) (L.J. Dorsman \& P.J. Knegtmans (eds.), Hilversum: Verloren, 2010, pp. 73-86.

\section{Gadamer 2013}

Hans-Georg Gadamer, Truth and Method, \#, London: Bloomsbury Academic 2013.

\section{Kant 2003}

Immanuel Kant, 'What Is Enlightenment?', in: H.S. Reiss (ed.), Political Writings, Cambridge: Cambridge University Press, 2003, 54-60.

\section{Kelman 1987}

Mark Kelman, A Guide to Critical Legal Studies, Cambridge: Harvard University Press. 


\section{Kennedy 1995}

Duncan Kennedy, 'Politicizing the Classroom', Review of Law and Women's Studies 1995, Nr. 4, p. 81-88.

\section{Kennedy 2004}

Duncan Kennedy, 'Legal Education and the Reproduction of Hierarchy', in: Duncan Kennedy, Legal Education and the Reproduction of Hierarchy. A Polemic against the System, New York: New York University Press 2004, p. 9-144.

\section{Kronman 2007}

Anthony T. Kronman, Education's End. Why Our Colleges Have Given Up on the Meaning of Life, New Haven: Yale University Press 2007.

\section{Latour 2013}

Bruno Latour, The Making of Law. An Ethnography of the Conseil d'Etat (translated by Marina Brilman and Alain Pottage; revised by the author), Cambridge: Polity Press 2013.

\section{Lembcke \& Van Klink (forthcoming)}

Oliver W. Lembcke \& Bart van Klink, Das mag in der Praxis richtig sein, taugt aber nicht für die Theorie‘. Zum Verhältnis zwischen Faktizität und Geltung bei Jellinek und Kelsen, in: Winfried Brugger †, Rolf Gröschner und Oliver W. Lembcke (eds.), Faktizität und Normativität. Georg Jellineks freiheitliche Verfassungslehre, Tübingen: Mohr Siebeck (forthcoming).

\section{Marquard 2007}

Odo Marquard, Skepsis in der Moderne, Stuttgart: Philipp Reclam jun. 2007.

\section{Norris 2002}

Christopher Norris, Deconstruction. Theory and Practice, London: Routledge 2002.

\section{Nussbaum 1997}

Martha C. Nussbaum, Cultivating Humanity. A Classical Defense of Reform in Liberal Education, Cambridge, Massachusetts: Harvard University Press.

\section{Nussbaum 1999}

Martha C. Nussbaum, 'Skepticism about Practical Reason in Literature and the Law', Harvard Law Review 1999, p. 714-744. 


\section{Nussbaum 2003}

Martha C. Nussbaum, 'Cultivating Humanity in Legal Education', The University of Chicago Law Review, 2003, p. 265-279.

\section{Oakeshott 2001}

Michael Oakeshott, The Voice of Liberal Learning, Indianapolis: Liberty Fund 2001.

\section{$\operatorname{Raz} 1979$}

Joseph Raz, The Authority of Law. Essays on Law and Morality, Oxford: Clarendon Press 1979.

\section{Sokhi-Bulley 2013}

Bal Sokhi-Bulley, 'Alternative Methodologies. Learning Critique as a Skill', Law \& Method 2013, nr. 1, p. 6-23.

\section{Van Klink 2011}

Bart van Klink, 'De kunst van het converseren. Over de rol van vaardigheden in Michael Oakeshotts opvatting van liberal learning', in: C.G. Breedveld-de Voogd (ed.), Signora Senatrice. Over recht, onderwijs en politiek. Opstellen aangeboden aan Ankie Broekers-Knol, Den Haag: Boom Juridische uitgevers 2011, p. 217225.

\section{Van Klink 2013}

Bart van Klink, 'The Role of Hierarchy, Example, and Language in Learning. A Confrontation between a Liberal and a "Critical" Understanding of Legal Education', Law \& Method, nr. 1, 2013, p. 26-47.

\section{Van Klink \& De Vries 2013}

Bart van Klink \& Bald de Vries, 'Skeptical Legal Education. How to Develop a Critical Attitude?', Law \& Method 2013, nr. 2, p. 37-52. 


\section{Weber 1989}

Max Weber, 'Science as a Vocation' (translated by Michael John), in: Peter Lassman, Irving Velody \& Herminio Martins (eds.), Max Weber's 'Science as a Vocation', London: Unwin Hyman 1989, p. 3-31.

\section{Waldenfels 1994}

Bernard Waldenfels, Antwortregister, Frankfurt am Main: Suhrkamp 1994.

\section{Wittgenstein 1977}

Ludwig Wittgenstein, On Certainty (translated by D. Paul and G.E.M. Anscombe), Oxford: Blackwell 1977. 